\section{MYELOPATHIC ALBUMOSURIA.*}

By T. R. BRADSHAW, B.A., M.D., M.R.C.P., Benior Assistant.Physician to the Liverpool Royal Infirmary.

If we may judge by the paucity of recorded cases, and by the silence of the textbooks on the subject, the disease which I have proposed to call myelopathic albumosuria must be one of the rarest with which we are acquainted. The textbooks, as I have said, are silent upon it, and the cases recorded in various publicaiions throughout Europe and America hardly amount to a dozen. It is, however, probable-nay, almost certain-that the condition is less uncommon than these figures would lead us to infer, and that cases are met with from time to time, though their true nature is not understood. As you will see by the table, the case which came under my observation was the first which had been recorded in Great Britain for half a century, and yet at the present time I know of two cases in the practice of members of the profession with whom I am acquainted. I feel therefore almost certain that if the condition were better known it would be more frequently recognised; and it is in the hope that such knowledge may lead to the discovery of further cases that I propose to bring the subject to your notice.

\section{Definition.}

Myelopathic albumosuria may be defined as a disease characterised by an invasion of the cancellous tissue of the bones of the trunk by a cellular growth, by a disappearance of the osseous tissue, and by the presence in the urine of large quantities of a peculiar albuminous substance belonging to the class of bodies known as albumoses.

\section{Morbid Anatomy.}

The morbid anatomy of the disease consists in a remarkable change in some of the bones, chiefly the ribs, sternum, and the bodies of the vertebræ. The hard substance is reduced often to a mere shell, which breaks on the slightest pressure with the fingers; the cancellous tissue has almost entirely disappeared; and spontaneous fractures of the ribs are common. The interior of the bone is occupied by a reddish gelatinous greasy mass, somewhat like splenic pulp, which can be readily squeezed out by pressure on the thin and brittle bone. Microscopically it consists of a vascular mass of cells, round or spindle-shaped, and in some cases islets of cartilage have been found. The whole structure resembles sarcoma, and the condition is generally known as " multiple myeloma."

This term we owe to Von Rustizky, who in 1873 described four cases of multiple tumours in bone. ${ }^{1}$ Whether these cases were of the same nature as those we are now considering remains doubtful, as there is no record of the condition of the urine. The organs as a rule are healthy. There is nothing characteristic in the kidneys: sometimes they appear to be healthy, sometimes they show blocking of the tubules and degenerative changes in greater or less degree.

\section{Syмpтомs.}

The disease is one occurring in the second half of life, and is apparently more frequent in men than in women. The symptoms may be classified under two heads-those connected with the affection of the bones, and those connected with the condition of the urine. In my case ${ }^{2}$ it was the condition of the urine which first suggested that anything was wrong; in the majority of cases the earliest symptoms were those connected with the bones. The first complaint is generally of pain in the lumbar region suggesting lumbago ; it is generally aggravated by movement; the patient probably looks anæmic, the pains do not yield to treatment; but there is nothing to suggest the serious nature of the case unless the condition of the urine, which I will presently describe, is recognised.

The pains vary much in severity from day to day, but on the whole become progressively worse, and the patient becomes disinclined for exertion. The pains become more general, being referred to the loins, the ribs, and the sternum, and tender spots arise in the course of the bones, which lose their normal rigidity to a remarkable extent. The chest wall seems.to yield to the pressure of the hand or the stethoscope, and actual fractures of the ribs take place either spontaneously A paper read at the autumn meeting of the North Wales Branch of the or from the exertion of an amount of force which would cause no discomfort or injury to a healthy person. A remarkable curvature of the spine appears and the mobility of the vertebral column is lost. In spite of the pain. weakness, and deformity, the patient is able to leave his bed and walk about until near the end of the case-a circumstance which is evidently due to the fact that the disease does not attack the bones of the extremities. In this respect it differs in a striking manner from another disease with which it has been sometimes confounded-namely, osteomalacia, in which the long bones are early affected, and the power of standing is lost almost from the first.

The Connition of the Urine.

The characteristic feature of the urine is the presence therein of a proteid which bears a superficial resemblance to albumin, but which can be easily shown to differ from albumin in several of its reactions. The characteristic reactions of the body are the following:

r. It coagulates at a comparatively low temperature $\left(60^{\circ} \mathrm{C} .=140^{\circ} \mathrm{F}\right.$.

2. The coagulum is redissolved on boiling.

3. It is readily precipitated by hydrochloric acid, as well as by nitric acid, and the precipitates are dissolved on boiling

I consider tbat the precipitation with hydrochloric acid, carefully carried out, is the most satisfactory test for bedside use. It requires no special apparatus, and if the urine is diluted well with water the reaction is quite distinctive. I have found it give a positive result when as much as 29 volumes of water had been added to the urine. It should be applied by the contact method.

The degree in which the coagula, which have been produced either by heat or acids, are soluble on boiling, varies somewhat in different specimens, and as a rule is less complete when the body is present in large amounts. A remarkable circumstance is that the albumose has a tendency to separate out spontaneously on standing. In my case this separation sometimes took place in the bladder or kidneys, so that the urine when voided looked like milk. It was this condition of the urine that first made the patient think there was anything the matter with him. I do not find this remarkable appearance recorded as having been observed in any other of the published cases, but a few of my medical friends have told me that they believed they had seen something like it.

\section{Diagnosis.}

The diagnosis of myelopathic albumosuria presents no difficulty to anyone who is acquainted with its symptoms, as the condition of the urine appears to be pathognomonic of the disease. In $\mathrm{my}$ case the condition of the urine was observed before any local signs of bone disease appeared, and in most if not all of the cases it is present when the patient seeks advice. In the early stage the disease may be mistaken for muscular rheumatism; when deformities appear it may be mistaken for osteomalacia or for tuberculous disease of the spine. On the other hand, the condition of the urine might lead to the diagnosis of large white kidney being made, or, if the albumose is spontaneously coagulated, to that of chyluria.

The disease seems to be almays fatal but sometimes its course is remarkably prolonged. In one instance the illness began eight years before death, and the albumose was known to be present for six years. As a rule cases seldom go on for a zear after the symptoms become so severe as to lead them to seek advice. Remarkable intermissions are frequently noticed in the progress of the cases which often give rise to false hopes of improvement. Death takes place from exhaustion or from some intercurrent disease, of which pneumonia appears to be the most frequent.

\section{Treatment.}

No treatment which has been tried hitherto has appeared to have the slightest effect on the progress of the disease. Anodynes are frequently called for, and great care must be used in handling and examining the patient, owing to the readiness with which fractures are produced.

Pathology.

The association of albumosuria with new growth in the bones is a remarkable fact which has no close analogy in any other disease. One is tempted to assume that the albumose 
is formed in the gelatinous masses in the bone and excreted in the urine, but no proof of this view has been offered, and against it we have the fact that similar new growths occur in other parts of the body without the appearance of anything unusual in the urine. Whatever their true connection may be, it cannot be denied that the formation of albumose in the body and its excretion in the urine is no less an essential part of the disease than is the existence of multiple myelomata. I think, therefore, that the term "myelopathic albumosuria" is a convenient one to apply to it, as it expresses the leading features of the condition without binding us to any theories as to the way in which they are associated.

Tabulated List of Published Cases in which "Bence Jones. Albumose" has been recognised in the Urine-"Myelopathic Albumosuria."

\begin{tabular}{|c|c|c|c|}
\hline 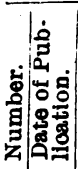 & Observer. & $\begin{array}{l}\text { Diagnosis during } \\
\text { Life. }\end{array}$ & $\begin{array}{l}\text { Condition found at } \\
\text { Necropsy. }\end{array}$ \\
\hline $\begin{array}{rl}9 & 1898 \\
\text { ro1 } 1899\end{array}$ & $\begin{array}{c}\text { Macintyre and } \\
\text { Bence Jones (London) } \\
\text { Kühne } \\
\text { Kahler (Prague) } \\
\text { Stokvis (Amsterdam) } \\
\\
\text { Stintzing (Jena) } \\
\text { Senator.(Berlin) } \\
\\
\text { Bozzolo (Tuwin) } \\
\text { Naunyn (Strassburg) } \\
\text { Bradshaw (Iiverpoof } \\
\text { Ellinger (Königsberg) } \\
\text { Fitz (Boston, U.S.A.) }\end{array}$ & $\begin{array}{c}\text { ? } \\
\text { Osteomalacia } \\
\text { Osteomalacia } \\
\text { ? } \\
\text { Osteomalacia or } \\
\text { multiple myeloma } \\
\text { Nephritis with } \\
\text { albumosuria } \\
\text { "Kahler's disease" } \\
\text { Multiple myeloma } \\
\text { Multiple myeloma } \\
\text { None made } \\
\text { Multiple myeloma }\end{array}$ & $\begin{array}{l}\text { Mollities ossium rubra } \\
\text { description . correspond } \\
\text { to multiple myeloma. } \\
\text { No necropsy made. } \\
\text { Multiple myeloma.s } \\
\text { Bones brittle; marrow } \\
\text { replaced by a red gela- } \\
\text { tinous mass.6 } \\
\text { Multiple myeloma.7 } \\
\text { " Myelogenous round - } \\
\text { celled sarcoma, so-called } \\
\text { myeloma." } \\
\text { No record.9 } \\
\text { No record.10 } \\
\text { Multiple myeloma.11 } \\
\text { Multiple myeloma.12 } \\
\text { Multiple myeloma.13 }\end{array}$ \\
\hline
\end{tabular}

NoTE.-Since this paper has been set up in type my attention has been drawn to a case published in 1899 by Buchstab and Schaposchnikow, of Odessa, in which the discovery of albumosuria led to a correct diagnosis
of the bone affection being made during life.14

\section{REFERENCES.}

1 Von Rustizky, J., Multiples Myelom., Deut. Zeit. f. Chir., Band iii, s, 163,1873 . 2 Bradshaw, T. R., A case of Albumosuria in which the Albumose was Spontaneously Precipitated, Med. Chir. Trans., 18g8. 3 Macintyre, William. Case of Mollities and Fragilitas Ossium accompanied with Urine, Wintrom, Case of Mollities and Fragilitas Ossium accompanied with Urine strongly charged with Animal Matter, Med. Chir. Trans., r850. p. 21 r. with Mollities Ossium, Phil. Trans., r84. Dalrymple, Juhn, On the with Mollities Ossium, Phil. Trans., 1848. Dalrymple, Juhn, On the Med. Science, 1846, p. 85. \& Kühne, W. Ueber, Albumose im Harne Med. Science, 1846, p. 85. 4 Kühne, W Ueber Albumose im Harne, Zeit. multiplen Myeloms, etc. Prager med. Woch, O., Zur Symptomatologie des multiplen Myeloms, etc., Prager med. Woch., 1889, N. 4, 5. Huppert, H., Jahresber. fon Thier-Chem., Bd. xxi, s.412; Bd. Xxii, s. 525 ; and Bd. xxiii, s. 577. 7 Seegelten, Ueber multiples 412 ; Bd. Xxii, 8. 525 ; and Bd. Xxili, Med.. Bd. Ivili, 1897, 8. 276. Matthes, M. Ueber Eiweiss-Körper im firin. bei Östeomalacie, Verhandl. des Congress $f$. innere Med. Xix. Neumeister, Lehrbuch des Phys. Chem., Aufl ii, 1897. s. 804. 8 Ueber einen eigenartigen Eiweiss-körper im Harne, etc., Berl. klin. Woch., 1897, No. 48. 9 Bozzolo, C., Sulla Malattia di Kahler; Atti dell', VIII Congresso di Medicina interna tenuto a Napoli, nell 'Ottobre, 1897. in Naunyn, Vereinsbeilage der deut. med. Woch., 1808, s. 217. 11 Bradshaw, T. R., loc. cit. Bradshaw, T. R and Warrington, W. B., The Morbid Anatomy and Pathology of Dr. Bradshaw's case of Myelopathic Albumosuria, .Ked. Chir. Trans., 1899 12 Ellinger, Alexander, Das Vorkommen des Bence Jones'schen Körpers im Harn bei Tumoren des Knochenmarks und seine diagnostische Bedeutung, Deut. Archiv f. klin. Med., 1899. ${ }^{13}$ Wright, J. H., A Case of Multiple Myeloma, Journal of the Boston Soc. of Med. Sciences, April, 1900. 14 Russ. Arch. f. Path., etc., Bd. vii, 1899.

\section{CONTRIBUTION TO THE TECHNIQUE OF BACTERIOLOGY.}

BY

MARC ARMANDRUFFER, \& MILTON CRENDIROPOULO M.D., M.D.,

President of the Sanitary, Maritime, Director of the Quarantine Station and Quarantine Board of Egypt. at Moses' Wells, Egypt.

Is the course of some investigations we found it necessary to invent a method by which the diffusible products of the life of micro-organisms could be obtained without subjecting the micro-organisms themselves, or the culture media, to the action of heat, filtration, or chemical reagents.
It is known that if certain microbes be introduced in a bag of filter paper or a sack of collodion and this bag placed under the skin of an animal, the toxins produced by the microbe pass through the walls into the surrounding tissues and give rise to toxic symptoms in that animal. We endeavoured to discover a technique by which these diffusible poisons or other diffusible products could be obtained in an ordinary culture tube.

The diagram shows how the problem was solved. The

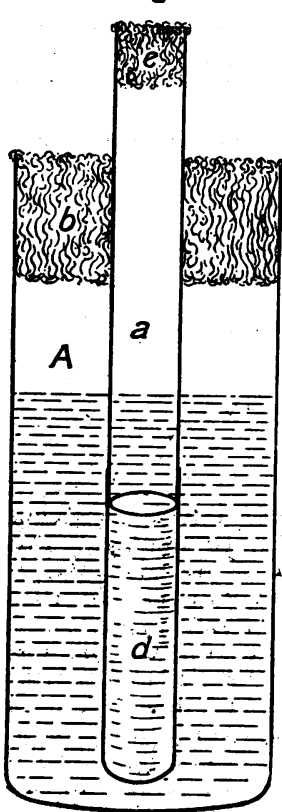
apparatus consists of an ordinary tegt tube a filled to any required level with bouillon or some other fluid cultivating medium, and plugged with cotton wool at $b$. Through this plug (b) another smaller glass tube $(a)$ is introduced to the lower extremity of which is attached a collodion sack $d$. This inner tube is filled to any required level with some cultivating fluid and is plugged at the upper extremity (e) with cotton wool.

We may now give some hints as to the preparation of these collodion bags, and their fixation, as we have not found in the literature at our disposal a good account as to the best method of making them. A small test tube is rapidly dipped bottom downwards into a small tumbler filled with collodion, until 2 or 3 inches of the tube are covered with collodion. It is then withdrawn and allowed to dry bottom upwards. After drying, the same process is repeated two or three times. The collodion is then found to stick tightly to the glass tube.

In order to separate the collodion from the glass tube, the whole is dipped alternately for a few seconds in strong spirit and then into water. The water and spirit diffusing through the collodion gradually loosen it from the glass. After a few minutes the collodion bag can easily be peeled off from the glass tube. A small glass tube of such a size that it can just enter the bag is then introduced into the open extremity of the collodion bag, and the whole is then placed in the incubator at $37^{\circ} \mathrm{C}$. The collodion bag now shrinks and tightly fits on the glass tube. All other methods of fastening the collodion bag have proved faulty in our hands, as the fastenings invariably allowed microbes to get through.

In order to sterilise the collodion glass tube (now called inner tabe), it is fixed in an empty test tube in the manner shown in the diagram, and the whole is sterilised at $150^{\circ} \mathrm{C}$. by dry heat on one or several occasions.

When this has been done the inner tube $(a)$ together with the plug $b$ are transferred aseptically to a tube of sterilised bouillon or gelatine of equal size, the plug $b$ now serving to close the tube of bouillon into which the inner tube is dipped. The bouillon in tube $a$ is now inoculated with the microorganism to be studied, and the whole placed in the incubator. The inner tube may also be filled to the required extent, introduced into the bouillon tube, and the whole sterilised in the autoclave. Experience, however, has shown us. that the first method is preferable. After a time the inner tube (a) is withdrawn, and the outer tube then contains the difIusible products which have been elaborated in the inner tube, and which have diffused through.

It is clear that this method can be used for a variety of purposes, as, for instance, the study of those products of the life of micro-organisms, which dialyse through a collodion membrane. By filling the outer tube with therapeutic serum, for example, antidiphtherial serum, and the inner tube with a diphtheria culture, the action of serum on the dialysable products of the diphtheria bacillus may be studied and inversely the action of dialysable constituents of therapeutic serum on the bacillus diphtheriæ and on its toxins.

By inoculating the liquid contained in the outer tube with one kind of micro-organism, and that of the inner tube with another, the lantagonism between two microbes may also be stadied, 